\author{
Ощепков О.П. \\ кандидат економічних наук, доцент \\ E-mail: moto47rod@gmail.com \\ Шкепу В.Ф. \\ магістрант \\ кафедра обліку та аудиту \\ Одеська національна академія харчових технологій \\ вул. Канатна, 112, м. Одеса, Україна, 65039 \\ E-mail: vikaskeopu@yandex.ru
}

\title{
ПОДАТОК НА ДОДАНУ ВАРТІСТЬ ТА ЙОГО РОЛЬ У ФОРМУВАННІ ДОХОДІВ ДЕРЖАВНОГО БЮДЖЕТУ УКРАЇНИ
}

\begin{abstract}
У статті досліджено сутність категорії «податок на додану вартість», якій є непрямим видом податку, котрий включається в ціну товарів, робіт та послуг на стадії їх реалізації. Визначено його роль у формуванні дохідної частини Державного бюджету України та проаналізовано динаміку його надходжень. Досліджено переваги та недоліки ПДВ, та питання правового регулювання оподаткування в процесі проведення економічних реформ, стимулювання розвитку бізнесу. Розглянуто питання удосконалення механізму адміністрування податку, обґрунтування рівня ставок податку та призначення податкових пільг.
\end{abstract}

Ключові слова: податки, Державний бюджет України, податкові надходження, податок на додану вартість, ставка податку, адміністрування податку.

This work is licensed under a Creative Commons Attribution 4.0 International License http://creativecommons.org/licenses/by/4.0/

Постановка проблеми та її зв'язок $з$ важливими науковими та практичними завданнями. У процесі реформування соціально-економічних відносин в Україні особливо актуальною $є$ проблема оподаткування господарських операцій, яка повинна стимулювати розвиток бізнесу i, на цієї основі своєчасно поповнювати доходну частину державного бюджету. Вирішення цієї важливої проблеми безпосереднє залежить від ефективності організації діяльності фіскальної служби, іiі об'єктивності та законності рішень, які приймаються по відношенню до бізнесу. Наскільки податкова система відповідає реаліям сьогоднішнього дня, стимулює розвиток реального сектора економіки і на цієї основі забезпечує зростання податкових надходжень до бюджету, буде характеризувати іiі ефективність. Особлива роль відводиться податку на додану вартість (ПДВ) як одного з основних бюджетоутворюючих податків у сучасній системі оподаткування в Україні

Аналіз останніх публікацій по проблемі. Дослідження ролі податку на додану вартість у формуванні доходів бюджету країни ставало предметом дослідження у працях багатьох вітчизняних та іноземних науковців, зокрема: О. Оксенюка, В. Кальчевського, П. Кулика та ін. Проблемами ефективності ПДВ займалися зарубіжні вчені-економісти, а саме: С. Аткінсон, Д. Боден, С. Брю, Л. Ебріл, М. Кін, К. Макконнелл, Н. Манків, Р. Харис та інші. Проте, зазначена тема і надалі залишається актуальною та потребує подальших досліджень як з теоретичної, так і 3 практичної точок зору. Разом з тим, необхідність подальшого удосконалення нарахування, перерахунку i адміністрування ПДВ, обумовлено динамічними процесами в суспільстві, зменшенням навантаження на бізнес та його стимулювання розвитку, яке безпосереднє зв'язано з ефективністю розвитку інструментарію адміністрування ПДВ та можливостей використання корупційних схем несплати податку або неправомірного його відшкодування.

Формулювання цілей дослідження. Ціллю статті є дослідження сутності поняття «податок на додану вартість», його недоліки та переваги, а також визначення ролі ПДВ у формуванні доходу Державного бюджету України та його адміністрування в сучасних умовах.

Виклад основних результатів та їх обгрунтування. Особливістю непрямих податків $\epsilon$ те, що їх безпосереднє використовують для наповнення бюджету країни, якій включається в ціну у вигляді надбавки, яку сплачує споживач.

Введення того чи іншого податку спрямовано на реалізацію стратегії податкової системи та визначення ролі цього податку в їі реалізації. Це передбачає, що податкова система, як складова фіскальної системи, повинна бути цілісною підсистемою в реалізації не тільки стратегії, але й тактичних кроків через іiі організацію. Як визначають ряд вчених, в тому числі Г.Минцберг, що стратегія і тактика передбачають наявність інструментів, за допомогою яких будуть реалізуватись стратегія і тактика [1]. 
Через впровадження непрямих податків держава має можливість впливати на купівельну спроможність споживачів тих або інших товарів, тим самим впливають на платоспроможний попит як невід'ємну складову ринкової рівноваги. Оскільки ПДВ має різні податкові ставки, важливе визначити, наскільки це ефективно, особливо запровадження пільгового оподаткування, нулеві ставки експортних операцій, тому що значні фіктивні операції через корупційні схеми дозволяють отримати бюджетні відшкодування. Так, в іноземній економічній літературі вка- зується, що ці питання спочатку обговорюються в рамках дискусії, яким чином це вплине на кінцеві податкові витрати, які замінюють бюджетні витрати [2].

Виходячи 3 функцій податків (економічної нейтральності, організаційної простоти, гнучкості податків, прозорості обліку і адміністрування), можна розглянути недоліки і переваги в системі оподаткування, характер яких буде наведено на прикладі ПДВ в табл. 1.

Переваги і недоліки непрямого податку (ПДВ)*

Таблиця 1

\begin{tabular}{|c|c|}
\hline Переваги & Недоліки \\
\hline $\begin{array}{c}\text { ПДВ виступає чинником, } \\
\text { регулюючим розмір ціни }\end{array}$ & ПДВ є чинником, що стримує розвиток виробництва \\
\hline $\begin{array}{c}\text { ПДВ постійним та стабільним } \\
\text { доходом держави }\end{array}$ & ПДВ є чинником, що стимулює інфляцію \\
\hline $\begin{array}{c}\text { ПДВ відрізняється простотою } \\
\text { стягування }\end{array}$ & $\begin{array}{l}\text { ПДВ - соціально несправедливий податок, оскільки він не залежить } \\
\text { від платоспроможності платника }\end{array}$ \\
\hline $\begin{array}{c}\text { ПдВ має механізм взаємної } \\
\text { перевірки платниками податко- } \\
\text { вих зобов'язань }\end{array}$ & $\begin{array}{l}\text { Шахрайства пов'язані з тіньовою економікою та корупційними схе- } \\
\text { мами о тримання відшкодування з бюджету }\end{array}$ \\
\hline
\end{tabular}

* складено авторами з використанням джерел [3]

ПДВ за сутністю є непрямий податок, зміст якого розкривається через поняття «податковий кредит та податкове зобов'язання». Згідно Податкового Кодексу України, податковий кредит дає право платнику податку зменшити податкові зобов'язання звітного періоду. Податкове зобов'язання відображає загальну суму податку, яка в звітному періоді. До бюджету перераховується сума ПДВ як різниця між податковим зобов'язанням і податковим кредитом, які нараховані в звітному періоді.

У праці “Економікс" К. Макконнелл та С. Брю визначили, що «додана вартість - це вартість проданого фірмою продукту мінус вартість сировини та матеріалів, придбаних і використаних фірмою для його виробництва, а також дорівнює виручці, що включає в себе еквівалент заробітної плати, орендної плати, процента та прибутку» [4, с.154]. Таким чином можна стверджувати, що додана вартість створюється на всіх стадіях виробництва i реалізації товарів i оплачується кінцевим споживачем.

Підтвердженням здійснення господарської операції за участю ПДВ є податкова накладна, як основний документ для суб'єкту господарювання, якій зареєстровано як платник ПДВ та яка є підставою для можливого отримання податкового кредиту від покупця та визначення податкового зобов'язання від продавця.

В зв'язку з переходом до електронної реєстрації податкових накладних, до них є загальні умови до оформлення, порядок їх оформлення визначено в наказі Мінфіну України №1307 від 31.12.2015 p. із відповідними змінами внесеними наказом №273 від 23.02.2017 р. Механізм електронної реєстрації податкових накладних і процес адміністрування ПДВ в електронному варіанті розглядається неоднозначне як 3 боку бізнесу так і фіскальними органами. Аналіз адміністрування ПДВ показує, що дана система має як позитивне значення, так і недоліки.

Використання системи електронного адміністрування ПДВ спрямоване на забезпечення безперервного контролю формування та відшкодування ПДВ 3 використанням електронного рахунку [5].

Фіскальна особливість ПДВ характеризується тим, що широка база оподаткування спростовує вплив кон'юнктурних коливань цін на ресурси, що відрізняє ПДВ від інших податків достатньо стабільною частиною доходу бюджету. Разом з тим, процес адміністрування ПДВ на сучасному етапі викликає велику кількість проблем та суперечливостей.

Про недоліки та суперечливості впровадження ПДВ розглядають ряд зарубіжних авторів. Так, в процесі дослідження даного питання К. Імран та Дж. Стігліц [6] прийшли до висновку, що вигоди від переходу до застосування ПДВ являються досить сумнівними, якщо частка тіньового сектора в економіці $\epsilon$ високою. Про низьку ефективність ПДВ в країнах, які розвиваються в напряму лібералізації зовнішньоекономічної діяльності вказують в своїх роботах 
Т. Баунсгард та М. Кін [7].

В механізмі електронного адміністрування ПДВ особливе визиває суперечливість впровадження «електронного рахунку « для сплати податку з боку платників податку, яке унеможливлю його сплати безпосереднє з поточного рахунку. На наш погляд, така сЗуперечність також пов'язана 3 процесом реєстрації податкових накладних. Для проведення реєстрації податкової накладної на електродному рахунку повинні бути достатнє коштів для виконання податкового зобов'язання.

Відмова від реєстрації податкової накладної може привести до невиконання контрактів, заказів, що приведе до втрати частини доходу платника податку i, відповідно, до скорочення відрахувань до бюджету. На нашу думку, на перехідний період треба залишити можливість сплати податку 3 поточного рахунку, тому що у більшості підприємств недостатнє власних вільних коштів, які повинні бути на електронному рахунку

Дійсно, електронне декларування дозволяє більш прозоро відлежувати процес адміністрування ПДВ, зменшувати ступень ризику з боку фіскальних органів неправомірних відшкодувань ПДВ, скорочення тоневої економіки.

Разом $з$ тим, виникає суперечливість в тому, Державна фіскальна служба виступає одночасно виконавцем і контролером електронного адміністрування ПДВ, що створює ризики неправомірних дій в системі з боку посадових осіб ДФС. Особливо це можливо при впровадженні штрафних санкцій за порушення надання податкових декларацій, за розблокування податкових накладних. Можливості неправомірних дій з боку фіскальних служб можливі в зв'язку з відсутністю розробленої методології визначення однозначності оцінки ступеню ризику в результаті неправомірних дій як з боку платника податку так і з боку персоналу фіскальної служби.

3 метою контролю за можливими порушеннями як з боку фіскальної служби так і платників податку в Азербайджанській Республіці було створено Департамент податкового аудиту, в задачі якого входить забезпечення якісного контролю за виконанням податкового законодавства, а також стимулювання працівників Департаменту в залежності від оцінки критеріїв якості, витрат часу і складності робіт. Реалі- зація такої програми стала можливою за рахунок впровадження інноваційних технологій [8].

Розглянути недоліки і переваги ПДВ можуть реалізуватись в тої або іншої мірі в залежності від законодавчої бази, яка буде стримувати або стимулювати їх. 3 точці зору платника податку, він є додатковими витратами, тому вони зацікавлені в зниженні цього податку, в результаті чого може збільшиться обсяг виробництва, більш наповнюватись ринок товарами, збільшаться суми відрахування до бюджету. Усунення цих недоліків, яке можна здійснити в досить короткі строки, дасть змогу зробити цей податок більш технологічним і придатним для застосування в Україні. Для підвищення ефективності оподаткування і прозорості системи адміністрування ПДВ

Подальше вдосконалення податкового законодавства та усунення окремих його недоліків позбавить противників цього податку. Відносним недоліком ПДВ є на сучасному етапі більш складний процес його адміністрування. Цим,а також рівнем розвитку економічної науки, пояснюється те, що ПДВ був «винайдений» і отримав широке поширення порівняно недавно [3].

Істотною проблемою в Україні є відшкодування ПДВ. Сумніви щодо потреби цього податку для країни виникають $з$ огляду на те, що:

- відбуваються масові зловживання під час нарахування ПДВ;

- виникають труднощі 3 відшкодуванням ПДВ [3];

- ПДВ включається в ціну товарів (робіт, послуг) та сплачується покупцем, але його облік та перерахування до державного бюджету здійснює продавець (податковий агент) [9].

На сьогоднішній день, ПДВ застосовується у багатьох країнах світу. Оскільки, наявність зазначеного податку $є$ однією із обов'язкових умов вступу країн до Європейського Союзу, але ставки податку відрізняються в різних країнах. 3 метою поповнення державного бюджету, ПДВ було введено і в Україні. На початку 1990-х років його ставка складала $28 \%$, але на сьогоднішній день іiі зменшено до 20\% [10]. Динаміку та структуру ПДВ, а також дані по бюджетному відшкодуванню за 2013-2016 роки, наведено в табл. 2 .

Таблиця 2

Динаміка надходження ПДВ до Державного бюджету України*

\begin{tabular}{|l|c|c|c|c|c|c|c|c|}
\hline \multirow{2}{*}{ Показники } & \multicolumn{2}{|c|}{2013 рік } & \multicolumn{2}{c|}{2014 рік } & \multicolumn{2}{c|}{2015 рік } & \multicolumn{2}{c|}{2016 рік } \\
\cline { 2 - 9 } & млн. грн. & млн. грн. & млн. грн. & $\%$ & млн. грн. & $\%$ & млн. грн. & $\%$ \\
\hline Податкове надходження, & 249746,1 & 83,25 & 326273,6 & 83,1 & 246939,1 & 79,9 & 329911,0 & 83,1 \\
\hline в т.ч.ПДВ: & 1542576,1 & 51,42 & 177112,0 & 54,2 & 185210,0 & 59,9 & 227950,0 & 57,51 \\
\hline $\begin{array}{l}\text {-3 виробництва товарів в Укра- } \\
\text { іні }\end{array}$ & 100602,1 & 33,45 & 103832,0 & 31,8 & 114750,0 & 37,1 & 140600,0 & 35,48 \\
\hline -з ввезених товарів & 112864,0 & 37,53 & 126620,0 & 38,8 & 138760,0 & 44,6 & 181450,0 & 45,70 \\
\hline - бюджетне відшкодування & 59500,0 & 19,58 & 53400,0 & 16,3 & 68400,0 & 22,1 & 94000,0 & 23,67 \\
\hline
\end{tabular}

* складено авторами з використанням джерел $[10,11,12]$ 
Аналіз наведених даних в таблиці показує, що питома вага податкового надходження в структурі доходів Державного бюджету України становить майже $83 \%$, питома вага ПДВ в структурі доходів збільшується з 51,42\% в 2013 році до 57,51\% в 2016 році. Таким чином, важливість цього податку зростає в наповнення бюджету. Також важливо підкреслити, більша частина цього податку отримана від імпорту. Це є негативний показник, який характеризує низькій рівень розвитку вітчизняного виробництва. Враховуючі суми відшкодування ПДВ, можна стверджувати, що імпорт значно перевищує експорт, що порушує валютний баланс держави.

Висновки та перспективи подальших досліджень. За результатами дослідження можемо зазначити, що ПДВ в системі оподаткування є основним бюджетоутворюючим податком. Для платника податку ПДВ є витратами. Виступаючи податком на кінцеве споживання, він, за доволі високої ставки є фактором стрімкої інфляції, а також стає одним із факторів, що стримують розвиток виробництва, тощо. В процесі дослідження встановлено, що непряме оподаткування в Україні потребує подальшого дослідження в напрямку використання заходів, які сприятимуть поступовому наближенню податкового законодавства України до законодавства СС.

Для того, щоб удосконалити механізм використання ПДВ, пропонується вирішення низки наступних питань:

- оптимізувати рівні ставок ПДВ з урахуванням пільг;

- удосконалити механізм адміністрування ПДВ 3 питань можливого блокування податкових накладних і механізм їх розблокування, максимально виключити можливість суб' єктивного впливу на даний процес;

- удосконалити критерії оцінки ступеня ризику;

- підвищити відповідальність як платників податку так і персоналу фіскальної служби за своєчасність і достовірність реєстрації податкових накладних, об' єктивної оцінки ступеню ризику при заблокуванні податкових накладних, а також однозначного підходу до впровадження штрафних санкцій.

\section{Література}

1.Минцберг Г. Стратегический процесс / Минцберг Ш., Дж.Куинн, С.Гошал; пер. с англ. под ред Ю.Н.Каптуревского. - СПб.: Питер, 2001. - 688 с.

2.Wildasin D.E. Tax Txpediiturex The Personal Standart. In «Tax Exspenditurex and Government Policy» (Ed.Bruce N.) .Kingston, 1988, p. 137

3. Щербина Ю. О. Переваги і недоліки податку на додану вартість / Ю. О. Щербина, Г. М. Рябенко // Студентський науковий вісник: науково-теоретичний журнал. - 2015. - № 1 (8). - С. 79-84.

4. Макконнелл Кемпбелл Р. Аналітична економія. Принципи, проблеми і політика / Кемпбелл Р. Макконнелл, Стенлі Л. Брю; пер.з англ. - Л.: Просвіта, 1997. - Ч.1: Макроекономіка - 1997. - 672c.

5. Податковий кодекс України 21.12. 2016 р. : за станом на 15 квітня 2017 р. [Електронний ресурс]. Режим доступу https://buhgalter911.com/normativnaya-baza/nalogovyi-kodeks/

6. Emran S. On selective indirect tax reform in developing countries [Електронний ресурс] / S. Emran, J. Stiglitz - Режим д доступу до ресурсу: https://www.gsb.columbia.edu/faculty/jstiglitz/download/2005_Indirect_Tax_Refor m.pdf.

7. Baunsgaard T. Tax revenue and (or?) trade liberalization [Електронний ресурс] / T. Baunsgaard, M. Keen - Режим доступу до ресурсу: http://papers.ssrn.com/sol3/papers.cfm?abstract_id=887981.

8. Мусаев А. Инновационные меры развития налоговой системы в Азербайджанской Республике / А.Мусаев // Економіст. - 2013. - №5. - С.25-28

9. Щербина Ю. О. Механізми регулювання непрямих податків в Україні: переваги та недоліки / Ю. О. Щербина, О. І. Мельник // Студентський науковий вісник. - 2015. - Вип. 1(12). - С.152-155.

10. Ціна держави. Бюджет України : за станом 19 березня 2017 р. [Електронний ресурс]. - Режим доступу: http://cost.ua/budget/revenue/

11. Кальчевський В. В. Роль податку на додану вартість у формуванні доходів державного бюджету України [Електронний ресурс] / B. В. Кальчевський. - Режим доступу: http://esnuir.eenu.edu.ua/bitstream/123456789/9389/1/\%D0\%9A\%D0\%B0\%D0\%BB\%D1\%8C\%D1\%87\%D0\%B5\%D 0\%B2\%D1\%81\%D1\%8C\%D0\%BA\%D0\%B8\%D0\%B9_\%D0\%92.pdf

12. Оксенюк О. І. Роль податку на додану вартість у формуванні доходів державного бюджету України / О. І. Оксенюк // Інноваційна економіка. - 2015. -№ 1. - С. 253-258. 


\author{
Ощепков А.П. \\ кандидат экономических наук, доцент \\ E-mail: moto47rod@gmail.com \\ Шкепу В.Ф. \\ магистрант \\ кафедра учета и аудита \\ Одесская национальная академия пищевых технологий \\ ул. Канатная, 112, г. Одесса, Украина, 65039 \\ E-mail: vikaskeopu@yandex.ru

\section{НАЛОГ НА ДОБАВЛЕННУЮ СТОИМОСТЬ И ЕГО РОЛЬ В ФОРМИРОВАНИИ ДОХОДОВ ГОСУДАРСТВЕННОГО БЮДЖЕТА УКРАИНЫ}

В статье исследована сущность категории «налог на добавленную стоимость», который определено, как косвенный налог, который включается в цену товаров, работ и услуг. Определена роль выше указанного налога в формировании доходной части Государственного бюджета Украины. Исследована динамика поступлений НДС в бюджет Украины. Обоснованы преимущества и недостатки косвенного налога на добавленную стоимость. Установлено, что финансовая система, которая включает отношения по поводу накопления и использования финансовых ресурсов государства, нуждается в реформировании важнейших ее составляющих, связанных с формированием бюджета и внебюджетных фондов. Учитывая то, что главным источником формирования доходной части бюджетов в Украине являются налоги, вопросы правового регулирования налогообложения относятся к числу наиболее актуальных при проведении социально-экономических преобразований на современном этапе. Именно поэтому налоговые реформы занимают главное место в процессе формирования рыночных отношений. Таким образом, объективная необходимость процесса перестройки налоговой системы Украины, анализ особенностей правового регулирования налогов и сборов, приобретает большое значение

Эффективная система налогообложения - неотъемлемая часть функционирования экономического комплекса любого современного государства, поскольку налоги - это не только основной источник поступлений в бюджеты, но и мощный регулятор общественных пропорций, гарант социальной защиты граждан и создание современной материальной основы суверенитета государства и местного самоуправления.

В работе рассматривается ряд требований при фрормировании налоговой системы, которая должна выполнять не только фискальную функцию, но и стимулировать развитие бизнеса с помощью диффреренциация ставок налогообложения, которые должны быть экономически обоснованы.

В работе рассмотрены вопросы администрирования налога на добеленную стоимость, особенности его осуществления в условиях электронного декларирования и регистрации налоговых накладных, а также возможности блокирования и механизма разблокирования налоговых накладных с учетом степени риска неправомерного получения возмещения из государственного бюджета НДС, а так же повышения ответственности работников фрискальной службы и плательщиков налога за выявленные нарушения через однозначную систему санкций.

Ключевые слова: налоги, Государственный бюджет Украины, налоговые поступления, налог на добавленную стоимость, налоговая ставка, администрирование налога.

\author{
Oshchepkov 0. \\ $\mathrm{PhD}$, Associate Professor \\ E-mail: moto47rod@gmail.com \\ Shkepu V. \\ Undergraduate \\ Department of Accounting and Auditing \\ Odessa National Academy of Food Technologies \\ Kanatna Str., 112, Odessa, Ukraine, 65039 \\ E-mail: vikaskeopu@yandex.ru
}

\title{
THE VALUE ADDED TAX AND ITS ROLE IN THE FORMATION OF REVENUES OF THE STATE BUDGET OF UKRAINE
}

The article studies the essence of the category "value added tax", which is defined as an indirect tax included in the price of goods, works and services. The role of the above mentioned tax revenues in the for- 
mation of the State budget of Ukraine has been determined. We investigated the dynamics of VAT revenue in the budget of Ukraine. The advantages and disadvantages of indirect tax on the value added have been substantiated. It has been established that the financial system, covering relations on the accumulation and use of financial resources of the state, needs reforming of the most important components connected with forming of the budget and extra-budget funds. Taking into account that the main source of formation of a profitable part of budgets in Ukraine there are taxes, regulatory issues related to taxation are among the most relevant. Given that the main source of formation of a profitable part of budgets in Ukraine there are taxes, regulatory issues related to taxation are among the most pressing in conducting socio-economic transformations I at the present stage. That is why tax reforms take the most important place in the process of market relations improvement. Taking into account the above mentioned the process of restructuring of the tax system of Ukraine, the analysis of the peculiarities of legal regulation of taxes and fees are of great importance.

An effective taxation system is an integral part of the functioning of the economic complex of any modern state, because taxes are not only the main source of budget revenues, but also a powerful regulator of social proportions, the guarantor of social protection of citizens and the creation of the modern material basis of the sovereignty of the state and local governments.

The paper discusses a number of requirements in the tax system, which is expected to carry out not only function, but also promote business development through the differentiation of tax rates which must be economically justified.

The paper considers the issues of tax administrations on the value added peculiarities of its implementation in terms of electronic Declaration and registration of tax invoices and the possibility of blocking and unblocking mechanism of tax invoices taking into account the risk of improper obtaining of reimbursement from the state budget of VAT as well as increasing the responsibility of employees of fiscal service and taxpayers for the violations through a simple system of sanctions.

Key words: taxes, State budget of Ukraine, tax revenues, value added tax, tax rate, tax administration.

\section{References}

1. Mintsberg, G., Kuinn, Dzh., \& Goshal, S. (2001). Strategicheskii protsess (I. N. Kapturevskii, Ed.). Sankt Peterburg: Piter.

2. Wildasin, D. E. (1988). Tax Txpediiturex The Personal Standart. In «Tax Exspenditurex and Government Policy» (N. Bruce, Ed.). Kingston.

3. Shcherbyna, Iu. O., \& Riabenko, H. M. (2015). Perevahy i nedoliky podatku na dodanu vartist. Studentskyi naukovyi visnyk: naukovo-teoretychnyi zhurnal, (1 (8)), 79-84.

4. Makkonnell, K. R., \& Briu, S. L. (1997). Analitychna ekonomiia. Pryntsypy, problemy i polityka(Ch.1: Makroekonomika). Prosvita.

5. Podatkovyi kodeks Ukrainy 21.12. 2016 r. : za stanom na 15 kvitnia 2017 r. (2017). Retrieved from https://buhgalter911.com/normativnaya-baza/nalogovyi-kodeks/

6. Emran, S., \& Stiglitz, J. (2005). On selective indirect tax reform in developing countries. Retrieved from https://www.gsb.columbia.edu/faculty/jstiglitz/download/2005_Indirect_Tax_Reform.pdf

7. Baunsgaard, T., \& Keen, M. (2006). Tax revenue and (or?) trade liberalization. Retrieved from http://papers.ssrn.com/sol3/papers.cfm?abstract id=887981

8. Musaev, A. (2013). Innovatsionnye mery razvitiia nalogovoi sistemy $\mathrm{v}$ Azerbaidzhanskoi Respublike. Ekonomist, (5), 25-28.

9. Shcherbyna, Iu. O., \& Melnyk, O. I. (2015). Mekhanizmy rehuliuvannia nepriamykh podatkiv v Ukraini: perevahy ta nedoliky. Studentskyi naukovyi visnyk, (1 (12)), 152-155.

10. Tsina derzhavy. Biudzhet Ukrainy: za stanom 19 bereznia 2017 r. (2017). Retrieved from http://cost.ua/budget/revenue/

Retrieved

11. Kalchevskyi, V. V. Rol podatku na dodanu vartist u formuvanni dokhodiv derzhavnoho biudzhetu Ukrainy.

http://esnuir.eenu.edu.ua/bitstream/123456789/9389/1/\%D0\%9A\%D0\%B0\%D0\%BB\%D1\%8C\%D1\%87\%D0\%B5\%D 0\%B2\%D1\%81\%D1\%8C\%D0\%BA\%D0\%B8\%D0\%B9_\%D0\%92.pdf

12. Okseniuk, O. I. (2015). Rol podatku na dodanu vartist u formuvanni dokhodiv derzhavnoho biudzhetu Ukrainy. Innovatsiina ekonomika, (1), 253-258. 